\title{
RELATIONSHIP BETWEEN PARENTAL ECONOMIC FACTORS, AND STUDENTS' DROPOUTS FROM GOVERNMENT SECONDARY SCHOOLS OF ZAMFARA, NIGERIA
}

\author{
Ahmad Kainuwa*, Najeemah Mohammad Yusuf and Jamalsafri Saibon \\ School of Educational Studies, Universiti Sains Malaysia, \\ 11800 USM Pulau Pinang, Malaysia \\ *Corresponding author: ahmadkainuwa@yahoo.com
}

Published date: 10 August 2018

To cite this article: Ahmad Kainuwa, Najeemah Mohammad Yusuf, \& Jamalsafri Saibon. (2017). Relationship between parental economic factors, and students' dropouts from government secondary schools of Zamfara, Nigeria. Asia Pacific Journal of Educators and Education, 32, 29-43. https://doi.org/10.21315/apjee2017.32.3

To link to this article: https://doi.org/10.21315/apjee2017.32.3

\begin{abstract}
This conceptual paper studies the relationship between parental economic factors and students' dropouts from government secondary schools of Zamfara, Nigeria. The paper reviews the studies on relationship between parental economic factors and students' dropouts. In addition, the paper also examines literature related to parental economic factors and students' dropouts from government secondary schools in both Nigeria and other countries. The discussion in the paper is based on the theoretical framework of ecological theory of Bronfenbrenner (1979). This theory is appropriate for the study because it allows the reader to understand how children's education is significantly affected by the parental economic factors. Finally, the paper provides and presents some suggestions and recommendations on how to improve student's retention and minimise the problem of dropout. Conclusions from the literature were drawn, and the paper concludes that parental economic factors are related to students' dropout.
\end{abstract}

Keywords: relationship, parental economic factors, students' dropouts, Zamfara, Nigeria

\section{INTRODUCTION}

The global figure of out of school and dropout children according to UNICEF are estimated at 121 million, with 65 million being female children and $80 \%$ of these female children are in Sub Saharan Africa. Despite the attention given to 
secondary school education, gender equality in education in terms of enrolment and completion as highlighted in the Dakar World Education Forum (UNESCO, 2000), there is still problem of secondary school dropout where many children in Sub-Saharan Africa and Nigeria in particular are being denied their fundamental human right (Driscoll, 2008) and consequently dropout from secondary schools. One of the key objectives of the World Education forum on Education for all adopted by the World Summit for Children in 1990 is universalizing access and promoting equity and minimizing problem of dropout in the area of education. This Forum identified provision of access, the improvement of quality education for male, female children and women, remove obstacles and parental factors that hampers their active participation and lead to their dropping out (Lawal, 2010).

The issue of school dropout in Nigeria especially Zamfara state has been with education system for a very long time. Fafunwa (1983) noted that dropout is one of the most serious problems that have continued to affect our educational system negatively since independence in 1960 from the colonial administration. Even before we got our independence, the problem of dropout has already established its grip on our educational system (Ajaja, 2012). Dropping out from school occurs after children have previously achieved access to school. A major problem in many developing countries, dropping out is often obscured within statistical data and by the emphasis on initial access (Hunt, 2008). Dropping out of students from secondary schools can be caused by many factors such as parental and school factors.

Economic factors of parent which include monthly family income, financial situation during the past years, engaging in selling, accessing of internet connection, organizing extra lessons, cost of transportation and cost of text books are found to be some of the contributing factors to secondary school dropout (Kainuwa, 2014). Children from some of the Nigerian states are not likely to enroll in school, and if they do it is unlikely they will complete primary and secondary education due to the high level of poverty. High levels of poverty often force parents to choose between food for the family and school for the children. This situation becomes magnified when looking at higher levels of education and contributes to the cycle of poverty passed on from generation to generation. Often parents choose to take their children out of school and involve them in activities that produce income, and many times these activities are illegal, immoral, and extremely detrimental to the lives of the children (National Bureau of Statistics, 2009; United Nations Millennium Goals, 2008). In Nigeria more especially in the study area, there is high poverty rate among parents which may be attributed to economic factors. This may have relationship with their inability to meet the financial demands for their children schooling (Yusuf, 2008). 


\section{BACKGROUND TO THE STUDY}

School dropout is a subject of major concern in most developed countries. Highschool dropouts experience considerably larger unemployment rates than their better-educated peers and are much more exposed to poverty and delinquency (Belfield \& Levin, 2007). In periods of economic stagnation, the gap between dropouts and other young people tends to increase over time, leading to rising polarization and concern for social cohesion. School dropout in its simplest meaning is the untimely withdrawal from school. These students who withdraw from school prematurely end up not obtaining any certificate of graduation. The issue of school dropout is a global problem confronting the education industry round the world. Researchers like; Bridgeland, Dilulio, and Morison (2006), and Oghuvbu (2008) have since buttressed this fact.

According to United Nation (2013), progression to the next education level is also a challenge. In fact, among class 6 students who are between 13 to 14 years, only $53 \%$ transitioned to secondary school. The secondary completion rate is even lower. A high percentage of students never finish secondary school and only $29 \%$ of those who started school graduated secondary school at the official graduating age of 17 years old. Even if there is a delay up to age 24 , only $75 \%$ finish secondary school and the remaining $25 \%$ never finish secondary school (United Nation, 2013).

The variables or indicators linked to secondary school dropout that were used for this study include parental economic factors which include monthly family income, financial situation, engaging in selling, having access to internet connection, organising extra lessons, cost of transportation, cost of text books to mention but a few.

\section{THEORETICAL PERSPECTIVES}

The study is based on human capital theory; the origin of human capital goes back to the emergence of classical economics in 1776, and thereafter developed a scientific theory (Fitzsimons, 1999). After the manifestation of that concept as a theory, Schultz (1961) recognized the human capital as one of important factors for a national economic growth in the modern economy. With the emergence and development of human capital as an academic field, some researchers expansively attempted to clarify how the human capital could contribute to sociopolitical development and freedom (Alexander, 1996; Grubb \& Lazerson, 2005). 
Broadly, the concept of human capital is semantically the mixture of human and capital. In the economic perspective, the capital refers to 'factors of production used to create goods or services that are not themselves significantly consumed in the production process' (Boldizzoni, 2008). Along with the meaning of capital in the economic perspective, the human is the subject to take charge of all economic activities such as production, consumption, and transaction. On the establishment of these concepts, it can be recognised that human capital means one of production elements which can generate added-values through inputting it.

Human capital is the stock of competencies, knowledge, habits, social and personality attributes, including creativity, cognitive abilities, embodied in the ability to perform labor so as to produce economic value. It is an aggregate economic view of the human being acting within economies, which is an attempt to capture the social, biological, cultural and psychological complexity as they interact in explicit and economic transactions (Becker, 1993). There are two ways in which the level of human capital may be relevant to education: the population's level of education and its English language proficiency. Most studies that have examined the education level of adopters of new technologies find that more educated people are quicker to adopt new innovations than people with comparatively less education (Rogers, 1983); in the case of the issue of dropout, this suggests that countries with better educated populations will be more likely to show lower rates of dropout than nations with less educated citizens and this is applicable to urban and rural areas.

Kelly and Petrazzini (1997) also suggest that academic institutions such as secondary school often play an important role in educating their students since they are often among the institutions in a nation to educate its citizens. This provides another reason for considering the education level of a nation in understanding the necessary and sufficient conditions for imparting knowledge. Higher scores on the education measure are likely to reflect a higher number of academic institutions because the scores reflect gross enrollment ratios.

\section{AIMS AND OBJECTIVES OF THE STUDY}

The purpose of this study is:

1. To review literature on relationship between parental economic factors and students' dropouts.

2. To review literature on dropout related to parental economic factors and students' dropouts from government secondary schools in other countries. 
3. To review literature on dropout related to parental economic factors and students' dropouts from government secondary schools in Nigeria.

4. To provide and present some suggestions and recommendations on how to improve student's retention and minimise the problem of dropout.

\section{LITERATURE REVIEW}

This section comprises of explanations on studies on the relationship between parental economic factors and students' dropouts, literature on dropout related to parental economic factors and students' dropouts from government secondary schools in both Nigeria and other countries, provide and present some suggestions and recommendations on how to improve student's retention and minimise the problem of dropout.

\section{Relationship between Parental Economic Factors, and Students' Dropouts}

Economic factors of parents play a crucial role in shaping the educational trajectories of children through the transmission of economic, resources which have direct bearing with secondary school student's retention and dropping out of school (Cheng, 2012). A number of studies highlight the linkage between poverty and dropping out from the school (Sabates, Akyeampong, Westbrook, \& Hunt, 2011; Birdsall et al., 2005). Poverty, jeopardise meaningful access to education for many children. As a result, many children are registered in schools but fail to attend, participate but fail to learn, are enrolled for several years but fail to progress and drop out from school.

Empirical evidence from other countries is rich and the main results seem to be in agreement with a priori expectation of a close link between economic factors of parents and secondary school student's dropout. Although the list is by no means exhaustive, the works of Ajaja (2012), Al-Fadhli and Kersen (2010), Akyeampong (2009), Atayi (2008), Sanda and Garba, (2007) and World Bank (2004) are among researches from within and outside Nigeria documenting the links between secondary school students' dropout and economic factors of parents.

Unavailability of parent's monthly family income and parent's financial situation have been found to be the major reason parents offer for not educating or dropping out of their children from secondary school. Frequency of eating was affected by many children's schooling to the extent that some parent's gross monthly income cannot cater for the family needs especially daily food and also support their 
education. As a result of low income some parents used to seek assistance of their children on farm. Jæger and Holm (2007) in one empirical analysis found that economic factors of parents are predictors of secondary education, in terms of attainment, retention and dropping out of school. On the other hand some parents with high economic factors frequently buy books for the benefit of their children and some usually subscribe to English language journals or magazines which are related to the economic factors of parents. Having Internet connection at home for children's education and organizing extra lesson for children's study are other issues usually documented in the previous researches which are also attributable to economic factors of parents (Pishghadam, \& Zabihi, 2011).

Previous researches (Cheng, 2012; Dan Wei, 2012) have established the independent effect of economic resources (which have to do with economic factors of parents) on secondary school student's education in different social, cultural, and national contexts. To understand the mechanism behind persistent educational stratification, Bourdieu's (1984) social reproduction theory provides a framework for explaining how economic, resources particularly economic factors of parents combine to influence secondary school student's education by preventing the problem of dropout.

However, in determining access to education by students and preventing the problem of dropout, economic factors of parents such as monthly family income and financial situation are found to be important factors; this is because there are many costs associated with schooling ranging from school fees, uniform PTA fees and the opportunity costs of sending a child to school. Economic factors of parents, financial support and family income are linked to a range of issues among which is the issue of secondary school student's dropout and non-dropouts: when children start school, how often they attend, whether they have to temporarily withdraw and also when and if they drop out (Bruneforth, 2006).

Cost of transportation to and from school on daily basis, provision of other daily monetary demands to the children, cost of text books and other school materials are found to be a burden for some of the parents which negatively affected the secondary education of their children. Research indicates links with household income, gender and dropping out; Grant and Hallman (2006) found an association with a family's financial strength, measured by level of household expenditure and access to credit, and the likelihood a daughter will remain in school in South Africa.

Children from better off households with better economic factors of parents are more likely to remain in school, whilst those who are poorer are more likely never 
to have attended, or to drop out once they have enrolled. This has been suggested by both statistical data and empirical research. For example, a research conducted in rural China by Glewwe, Kremer, Hanushek and Welch (2006) saw 'poor and credit constrained children' three times more likely than other children to drop out of school. The links between wealth and school retention has been described in more detail by Colclough, Rose and Tembon (2000, cited in Ananga, 2011), where he stated that "amongst those out-of-school, the mean wealth index for school drop-outs was generally higher than for those who had never enrolled ... children at school were, on average, from better-off households than those who had dropped out, who were, in turn, from richer backgrounds than school-age children who had never enrolled".

\section{Studies on Dropout Related to Parental Economic Factors and Students' Dropouts from Government Secondary Schools in other Countries}

In the United State of America, Tyler and Lofstrom (2009) conducted a study titled Finishing secondary school: Alternative pathways and dropout recovery, the future of children. The researchers mentioned that overall national dropout rate appears to be between $22 \%$ and $25 \%$, a student's decision to drop out of school, say the authors, is affected by a number of complex factors and is often the culmination of a long process of disengagement from school. That decision, not surprisingly, carries great cost to both the student and society. Individual costs include lower earnings.

Balfanz and Letgers (2004) as in Burrus and Roberts (2012) found a strong relationship between poverty and the dropout rate in the United States: The authors found that the higher the percentage of a school's students living in poverty, the higher the dropout rate. Poverty seems to be one of the strongest, if not the strongest, predictor of a school's dropout rate.

Collins (2009) conducted a study on the variables that impact high-school dropout rates in a large metropolitan area; the purpose of the study was to determine the variables associated with higher dropout rates in secondary schools in a large metropolitan area in the south-eastern U.S. The study identified variables most useful in predicting high-school dropout rates in the metropolitan area, while the dropout crisis affects students from all socioeconomic levels; dropout rates are higher for students of lower socioeconomic status. Collins (2009) said some research indicates that students who attend schools located in urban areas are at much greater risk for dropping out of school than students in suburban and rural areas. 
Okumu et al. (2008), in their researches on socioeconomic determinants of primary school dropout in Uganda, they found that high academic attainment of the parents significantly reduces chances of primary school drop out for both boys and female children in rural and urban areas. Akinsanya, Ajayi and Salomi (2011) maintained that that parents' occupation and educational level will affect students' education. Marks (2011), Galobardes, Shaw, Lawlor, Lynch \& Smith (2006) affirmed that parent's financial support has greater influence on students' enrolment, retention and completion despite all the research and policy making, The relativity between those of high and low status from among the parents in relation to their children is widening rather than narrowing across educational achievement in terms of enrolment and dropping out of schools (Conger \& Donnellan, 2007). Similarly, studies from Kenya, Mali, Malawi, Democratic Republic of Congo and Uganda found that children from poor households were less likely to be enrolled and stay in schools because of school fees, text books, school uniforms etc., (UNESCO, 2006a; 2006b).

Many countries in sub-Saharan Africa have succeeded in universalizing primary education, a number still find it a challenge to provide meaningful access to education for their population (UNESCO, 2010; Oladele, 2013; Lewin, 2009). According to Lewin and Akyeampong (2009) sub-Saharan Africa is still below par in terms of achieving access to education compared to other regions in the world. A large proportion (53.5\%) of out of school children are found in this region. Of these, 32.2 million are at the primary and 21.3 million at the secondary levels of schooling respectively (UNESCO, 2009).

Not only is access to education a challenge in Africa at large and sub-Saharan Africa in particular, but also retention once children are in school. The EFA Global Monitoring Summary Report (UNESCO, 2010) indicates that 38 million children dropped out from both primary and secondary school in sub-Saharan Africa; an issue that goes beyond access to that of retention. Though getting children into school is a vital first step, the larger challenge in many countries in Africa centers on keeping them in school. To receive the full benefits of access to education, questions have been raised about the more serious problems of retention and the experiences of children in school that contribute to them either dropping out or staying in school (Oladele, 2013).

Ampiah and Adu-Yeboah (2009) in their work titled "Mapping the incidence of school dropouts: A case study of communities in Northern Ghana". In some households, children said they were expected and encouraged to contribute to family subsistence by providing labor on farms for their parents and other relatives. Some also worked for other farmers to generate income for their own upkeep. 
Involvement in farming activities during school times occurred more frequently in rural areas than in the semi-urban communities, especially during the months of June and July, when farming activity was at its peak. For households and children facing financial difficulties the farming season required their full participation. During this time school took on secondary importance. Household poverty was often cited as a factor contributing to drop out. Over $20 \%$ cited this as an important contributory factor to eventual dropout. The dropouts said they felt compelled to work, either to contribute to family income or for their own upkeep.

\section{Studies on Dropout Related to Parental Economic Factors and Students' Dropouts from Government Secondary Schools in Nigeria}

Educating the population is perceived as crucial to a nation's future prospects and formal education has throughout the last decades become accessible to, and close to necessary for, the broader part of society (Borgen \& Borgen, 2014; Bailey, 2007). Unfortunately, the share of birth cohorts completing secondary school remains undesirably low in Nigeria, many Western countries and the world at large (Borgen \& Borgen, 2014). Pupils who drop out of secondary school create a low-skilled labor force. A low-skilled labor force is related to negative economic consequences like limited economic growth (Bailey, 2007), limited tax income (Rouse, 2007), increased welfare expenditure (Waldfogel, Garfinkel, \& Brendan, 2007), and even increased crime rates and drug abuse (Moretti, 2007). Hence, the society will benefit from enhancing the completion rate of secondary education.

As said earlier the crisis of secondary school dropouts is not peculiar to Nigeria but an international problem and the prevalence of drop out varies between and within countries and occurs more frequently in certain locations (Collins, 2009) age ranges and grades and it was caused by many factors depending on the educational structure and patterns of participation in that country. In the case of Nigeria poverty also seems to be one of the strongest contributing factors of student's dropout. This had been confirmed by the research conducted by Sanda and Garba (2007) based on data collected from 600 rural households of Sokoto State, Nigeria which provided empirical evidence on the extent to which parental financial support, poverty and household demographic characteristics may affect educational attainment, school attendance, dropout and non-dropout of children.

Nathaniel (2011) conducted a study titled: School dropout among Nigerian children: some proactive strategies and solutions in Port Harcourt, Nigeria. The study suggests that Nigeria should adopt 'proactive' rather than 'damage control' strategies (increased capacity building, recruitment and appropriate deployment of teachers, provision of necessary infrastructures including library and laboratory 
facilities, as well as increased financial) in systematically dealing with this rising out-of-school syndrome.

Based on the fore going discussions of statistical data and empirical researches in the reviewed literatures, it could be evidently agreed that the parental economic factors that have to do with financial support and financial well-being of the family greatly affects the participation of students in schooling and minimise the high level of secondary school student's dropout.

\section{Suggestions and Recommendations on how to Improve Student's Retention and Minimise the Problem of Dropout}

Taking into account the extent to which parental economic factors are affecting secondary school student's education, the following recommendations might be helpful to authorities and the whole community to tackle adequately the issue of secondary school student's education. Education is the weapon that breaks the bond of ignorance and poverty, if this is understood by the parents and guardian, and then it will encourage them to do all within their powers to send their children to school despite all odds. Providing suggestions to lessen the problem of students' dropout, the paper suggested that parents should be educated. Community development programs like adult education programs need to be encouraged in order to systematically reduce the prevalence of dropouts. There should be public awareness campaign to parents so that they can give their children the best they can in terms of education including the promotion of other co-curricular activities. Community based childcare services may help children to get time to continue attending schools. Labour saving technologies and water close to homes may free children from spending long hours in domestic work. More female teachers and administrators should be employed in government junior secondary schools. This brings successful role models very close to students particularly in rural areas.

The paper also suggested that parents' should be introduced to certain occupations to improve their standard of living in order to lessen the problem of dropout. The paper also add that the institutional and administrative actions are required to minimise the prevalence of dropouts: The existence of this problem on a considerable scale implies that more has to be done to minimise the situation in Zamfara state. Experience from Zamfara state tells that institutional and legal actions are required to reduce the incidence of dropouts both in Shinkafi and elsewhere. It is also needed to strictly follow the policy of automatic promotion so that those who come to school are encouraged. 
Considering the general poverty of families in Nigeria, the government, at all levels should give priority to the funding of education and equip the schools with relevant teaching text books and learning materials. The government should also provide financial or material incentives by adopting a poverty-alleviation strategy, particularly for households headed by women and low financial support families is essential in the long run. Unless some income generating activities involving women parents are set in motion, the problem seems likely to continue to affect female children for a long time to come. In the short run, it is required that providing female students with financial support to buy pens, pencils, books or materials for clothing will help to solve some of the barriers to stay in schools. A policy strategy and action have to be adopted by the government and donors to assist in providing these grants and there should be a control mechanism to ensure that these materials have been distributed and used properly. This was suggested by 5 teachers during the interview in relation to financial support, of the parents. They suggested the establishing of the institution of loan scheme and provision of instructional materials at moderate price or free.

\section{CONCLUSION}

Findings about parental economic factors ascertain that the majority of secondary school dropouts come from households headed by low income families; most parents of secondary school dropouts are engaged in low income generating occupations in the informal sector and earn or possess an insignificant amount of property. The dropping out of secondary school students in this study has generally been related to the low parental economic factors. This is particularly true for rural areas such as villages and less so in urban areas such as towns and cities. The paper attempted to examine the issues surrounding secondary school education in Zamfara state Nigeria, more especially parental economic factors in the area, reviews the studies on relationship between parental economic factors and students' dropouts. The paper also went on to examine literature related to parental economic factors and students' dropouts from government secondary schools in both Nigeria and other countries. The paper provided and presented some suggestions and recommendations on how to improve student's retention and minimise the problem of dropout. Finally, the paper concludes that parental economic factors are related to students' dropout. 


\section{REFERENCES}

Ajaja, O. P. (2012). School dropout pattern among senior secondary schools in Delta state, Nigeria. International Education Studies, 5(2), 145. https://doi.org/10.5539/ies. v5n2p145

Akinsanya, O. O., Ajayi, K. O., \& Salomi, M. O. (2011). Relative effects of parents' occupation, qualification and academic motivation of wards on students' achievement in senior secondary school mathematics in Ogun State. British Journal of Arts and Social Sciences, 3(2), 242-252.

Akyeampong, K. (2009). Public-private partnership in the provision of basic education in Ghana: challenges and choices. Compare: A Journal of Comparative and International Education, 39(2), 135-149. https://doi. org/10.1080/03057920902750368

Al-Fadhli, H. M, \& Kersen, T. M. (2010). How religious, social, and cultural capital factors influence educational aspirations of African American adolescents. The Journal of Negro Education, 79(3), 380-389.

Alexander, K. (1996). The value of an education. In D. W. Breneman, L. L. Leslie, \& R. E. Anderson (Eds.), ASHE Reader on Finance in Higher Education (pp. 85-111). Needham Heights, MA: Simon \& Schuster [Originally published 1976].

Ampiah, J. G., \& Adu-Yeboah, C. (2009). Mapping the incidence of school dropouts: A case study of communities in Northern Ghana. Comparative Education, 45(2), 219-232. https://doi.org/10.1080/03050060902920625

Ananga, E. (2011). Dropping out of school in southern Ghana: The push-out and pull-out factors. CREATE Pathways to Access Series (Research Monograph No. 55).

Atayi J. B. (2008), Disabling barriers to girls'primary education in Aura district (Uganda): An intersectional analysis. A Research Paper presented in partial fulfillment of the requirements for obtaining the degree of Masters of Arts in Development studies.

Bailey, T. (2007). Implications of educational inequality in a global economy. In C. R. Belfield \& H. M. Levin (Eds.), The price we pay: Economic and social consequences of inadequate education (pp. 74-95). Washington, DC: Brookings Institution Press.

Balfanz, R., \& Letgers, N. (2004). Locating the dropout crisis: Which secondary schools produce the nation's dropouts? Where are they located? Who attends them? Baltimore, MD: Center for Social Organization of Schools, Johns Hopkins University.

Becker, G. S. (1993). Human capital: A theoretical and empirical analysis with special reference to education (3rd ed.). Chicago: University of Chicago Press. https://doi.org/10.7208/chicago/9780226041223.001.0001

Belfield C., \& Levin H. (2007), The price we pay: Economic and social consequences of inadequate education. Washington, DC: The Brookings Institution.

Birdsall, N., Levine, R., \& Ibrahim, A. (2005). Towards universal primary education: Investments, incentives, and institutions. European Journal of Education, 40(3), $337-349$.

Boldizzoni, F. (2008). Means and ends: The idea of capital in the West; 1500-1970. New York: Palgrave Macmillan. https://doi.org/10.1057/9780230584143 
Borgen, S. T., \& Borgen, N. T. (2014). Folk secondary schools and dropouts from upper secondary school: effects of non-academic investments in dropouts. School Effectiveness and School Improvement, 26(2), 153-168.

Bourdieu, P. (1984). Distinction. A social critique of the judgement of taste. Cambridge, MA: Harvard University Press.

Bridgeland, J. M, Dilulio, J. J., \& Morison, K. B. (2006). The silent epidemic. New York: Civic Enterprises, LLC.

Bronfenbrenner, U. (1979). The ecology of human development. Cambridge, MA: Harvard University Press.

Bruneforth, M. (2006). Characteristics of children who drop out of school and comments on the drop-out population compared to the out-of school population. Education for All (EFA) Global Monitoring Report, UNESCO.

Burrus, J., \& Roberts, R. D. (2012). Dropping out of secondary school: Prevalence, risk factors, and remediation strategies. $R \& D$ Connections, 18. Retrieved from https://www.ets.org/Media/Research/pdf/RD_Connections18.pdf

Cheng, S. T. (2012). Cultural capital, economic capital, and academic achievement: some evidence from Taiwan. Unpublished doctoral dissertation, Michigan State University.

Colclough, C., Rose, P., \& Tembon, M. (2000). Gender inequalities in primary schooling: the roles of poverty and adverse cultural practice. IDS Working Paper No. 78. Brighton: Institute of Development Studies.

Collins, D. B. (2009). Variables that impact high-school dropout rates in a large metropolitan area. Doctoral dissertation, University of Georgia.

Conger, R. D., \& Donnellan, M. B. (2007). An interactionist perspective on the socioeconomic context of human development. Annual Review of Psychology, 58, 175-199. https://doi.org/10.1146/annurev.psych.58.110405.085551

Dan Wei. (2012). Parental influence on Chinese students' achievement: A social capital perspective, Asia Pacific Journal of Education, 32(2), 153-166. https://doi.org/1 $0.1080 / 02188791.2012 .684951$

Driscoll, C. C. (2008). Girls Today: Girls, girl culture and girl studies. Girlhood Studies, $1(1), 13-32$.

Fafunwa, A. B. (1983). Dropout in the Nigeria education system. In S. A. Adesina, \& E. Ajayi (Eds.), Nigeria education trends and issues. Ile Ife: University of Ife Press.

Fitzsimons, P. (1999). Human capital theory and education. In Encyclopedia of Philosophy of Education (pp. 1-4). Auckland: University of Auckland.

Galobardes, B., Shaw, M., Lawlor, D. A., Lynch, J. W., \& Smith, G. D. (2006). Indicators of socioeconomic position (part 1). Journal of Epidemiology and Community Health, 60(1), 7-12. https://doi.org/10.1136/jech.2004.023531

Glewwe, P., Kremer, M., Hanushek, E., \& Welch, F. (2006). Schools, teachers, and education outcomes in developing countries. In E. Hanushek, \& F. Welch (Eds.) Handbook of the Economics of Education (pp. 945-1017). North Holland: Elsevier.

Grant, M., \& Hallman, K. (2006) Pregnancy related school dropout and prior school performance in South Africa. Policy Research Division Working Paper No 212. New York: Population Council. 
Grubb, W. N., \& Lazerson, M. (2005). The education gospel and the role of vocationalism in American education. American Journal of Education, 111(3), 297-319.

Hunt, F. (2008). Dropping out of school: Across country review literature. Create Pathways to Access (Research Monograph No. 16).

Jæger, M. M., \& Holm, A. (2007). Does parents' economic, cultural, and social capital explain the social class effect on educational attainment in the Scandinavian mobility regime? Social Science Research, 36(2), 719-744.

Kainuwa A. (2014). Parental factors on female muslim students'dropout from government junior secondary schools of Shinkafi, Nigeria. Unpublished Master's Thesis, School of Educational Studies, Universiti Sains Malaysia.

Kelly, T. \& Petrazzini, B. (1997). What does the internet mean for development? Paper presented at Telecom Interactive Development Symposium, Geneva, Switzerland, 11 September 1997.

Lawal, A. H. (2010). Development intervention in basic education: Enhancing the girlchild education in rural communities of Northern Nigeria. Research paper, Institute of Social Studies, The Hague, The Netherlands.

Lewin, K. M., \& Akyeampong, K. (2009). Education in sub-Saharan Africa: Researching access, transitions and equity. Comparative Education, 45(2), 143-150. https://doi.org/10.1080/03050060902920492

Lewin, K. M. (2009). Access to education in sub-Saharan Africa: Patterns, problems and possibilities. Comparative Education, 45(2), 151-174.

Marks, G. N. (2011). Issues in the conceptualization and measurement of socio-economic background: Do different measures generate different conclusions? Social Indicators Research, 104(2), 225-251.

Moretti, E. (2007). Crime and the costs of criminal justice. In C. R. Belfield, \& H. M. Levin (Eds.), The price we pay: Economic and social consequences of inadequate education (pp. 142-159). Washington, DC: Brookings Institution Press.

Nathaniel, M. A. (2011). School dropout among Nigerian children: Some proactive strategies and solutions African Journal of Education and Technology, 1(3), 118124.

National Bureau of Statistics (Nigeria). (2009). Annual abstract of statistics, 2009. Abuja, Nigeria: National Bureau of Statistics (Nigeria).

Oghuvbu, E. P. (2008). The perceived home and school factors responsible for dropout in primary schools and its impact on national development. Ekpoma Journal of Behavioural Sciences, 1, 234-235.

Okumu, I. M., Nakajjo, A., \& Isoke, D. (2008). Socioeconomic determinants of primary school dropout: the logistic model analysis. MPRA Paper No. 7851. Retrieved from https://mpra.ub.uni-muenchen.de/7851/

Oladele M. A. A. (2013). An investigation into factors that shape secondary school female retention in two rural public schools, Alimosho Region, Lagos State, Nigeria. Unpublished Masters thesis, Rhodes University.

Pishghadam, R., \& Zabihi, R. (2011). Parental education and social and cultural capital in academic achievement. International Journal of English Linguistics, 1(2), 50-57. https://doi.org/10.5539/ijel.v1n2p50

Rogers, E. M. (1983). Diffusion of innovations. New York, NY: The Free Press. 
Rouse, C. E. (2007). Consequences for the labor market. In C. R. Belfield \& H. M. Levin (Eds.), The price we pay: Economic and social consequences of inadequate education (pp. 99-124). Washington, DC: Brookings Institution Press.

Sabates, R., Akyeampong, K., Westbrook, J., \& Hunt, F. (2011). School dropout: Patterns, causes, changes and policies. Background paper prepared for the Education for All Global Monitoring Report, UNESCO.

Sanda A., \& Garba, T. (2007). Rural household poverty school attendence and educational attainment. Evidence from Sokoto state Nigeria: The African symposium. An online Journal of Educational Research Network, 7(1), pp.

Schultz, T. W. (1961). Investment in human capital. American Economic Review, 51, 1-17.

Tyler, J. H., \& Lofstrom, M. (2009). Finishing high school: Alternative pathways and dropout recovery. The Future of Children, 19(1), 77-103.

United Nations. (2008). United Nations millennium development goals. Retrieved from http://mdgs.un.org/unsd/mdg/Host.aspx?Content=indicators/officiallist.htm

United Nations. (2013). Accelerating progress to 2015 Nigeria. A report series to the UN Special Envoy for Global Education. Working paper, United Nation.

United Nations Education, Scientific and Cultural Organization (UNESCO). (2000). Final report. World Education Forum, Dakar, Sinegal, 26-28 April 2000. Retrieved from http://unesdoc.unesco.org/images/0012/001211/121117e.pdf

UNESCO. (2006a). EFA global monitoring report 2007: Strong Foundations. Early Childhood Care and Education. Paris: United Nations Education, Scientific and Cultural Organization (UNESCO).

UNESCO. (2006b). The education for all development index (EDI).

UNESCO. (2009). EFA global monitoring report 2009: Overcoming inequality: Why governance matters. Retrieved 10 June 2011, from http://www.sociolingo. com/2009/07/2009-education-for all-globalmonitoring-report-africa/

UNESCO. (2010). EFA global monitoring report 2010: Reaching the marginalized. Paris: United Nations Education, Scientific and Cultural Organization (UNESCO). Retrieved from http://unesdoc.unesco.org/images/0018/001866/186606E.pdf

Waldfogel, J., Garfinkel, I., \& Brendan, K. (2007). Welfare and the costs of public assistance. In C. R. Belfield \& H. M. Levin (Eds.), The price we pay: Economic and social consequences of inadequate education (pp. 160-176). Washington, DC: Brookings Institution Press.

World Bank (2004). World Development Report 2004: Making Services Work for Poor People. Washington, DC: World Bank.

Yusuf, A. (2008). Economic and socio-cultural impediments to girl-child education in Sokoto, Implication for Universal Basic Education. Unpublished Master's thesis. 